\title{
РАЗРАБОТКА УНИВЕРСАЛЬНОГО СПОСОБА ПОЛУЧЕНИЯ 6-(АРИЛЗАМЕЩЕННЫХ)-2,4-ДИАМИНО-СИММ-ТРИАЗИНОВ
}

\author{
Ю. В. Попов, Т. К. Корчагина, В. С. Лобасенко, И. В. Букова, Н. В. Немцева
}

В данной статье описывается способ получения 2,4-диамино-симм-триазинов, содержащих дифренилоксидный фрагмент и обладающих потенциальной биологической активностью. На основе ранее используемых методов был разработан универсальный способ и подобраны оптимальные параметры процесса получения замещенных 2,4-диамино-триазинов. Предложенный метод позволяет значительно упростить стадию и увеличить выход выделения целевого продукта. Для данного способа получения был приведен механизм образования целевого продукта. Обладание потенциальной биологической активностью - противоспалительной, антиаллергической - обуславливает актуальность и необходимость применения данного синтеза в промышленных масштабах. Для веществ 2,4-диамино-триазинов, которые могут быть получены данным методом, была разработана и описана принципиальная технологическая схема получения для одного из возможных целевых продуктов - 6-(3-Феноксифенил)2,4-диамино-симм-триазина. Данный однореакторный метод получения позволяет достигать высокого выхода, достигающий до 90 \%. Синтез ведут в присутствии растворителя ДМФА в течение 10 ч, а затем продукт перекристаллизовывают и очищают от примесей. Разработанная схема получения подходит и для других производных триазинов, которые могут быть получены по данной методике, что доказывает еѐ практическую значимость и промышленную применимость.

Ключевые слова: биологическая активность, гетероциклические соединения, дифенилоксид, иминоэфир, нитрил, реакторный узел, способ получения, технология, технологическая схема, триазины.

Гуанамины (6-арилзамещенные 2,4-диамино-симм-триазины) представляют интерес как сырье для производства полимеров (гуанаформальдегидных смол) [1, 2], как компоненты антипиренов (замедлителей горения) [3]. Многие гуанамины обладают выраженной биологической активностью, способствуют заживлению пептических язв [4], обладают противовоспалительной активностью [5], антиаллергической [6] и диуретической активностью [7].

На базе семейства триазинов разработан препарат широкого спектра действия - «триазаварин». Препарат защищает на 60-90 \% от инфекций, вызываемых вирусами Крымской геморрагической лихорадки, лихорадки долины Рифт, вирусами клещевого энцефалита, вирусами гриппа (в том числе вирусами гриппа птиц H5N1), респираторно-синцитиальной инфекции [8]

Ранее авторами [10] было установлено, что процесс получения симм-триазинов из нитрилов и дициандиамида возможен только в 2-метоксиэтаноле или смеси 2-метоксиэтанола с диметилсульфоксидом. Механизм реакции в этом случае представляет следующий вид: сначала происходит присоединение алкоксид-иона (образующегося из 2-метоксиэтанола и КОН) к нитрилу с образованием аниона иминоэфира, находящегося в равновесии с иминоэфиром. Далее анион иминоэфира присоединяется к дициандиамиду по схеме 1:

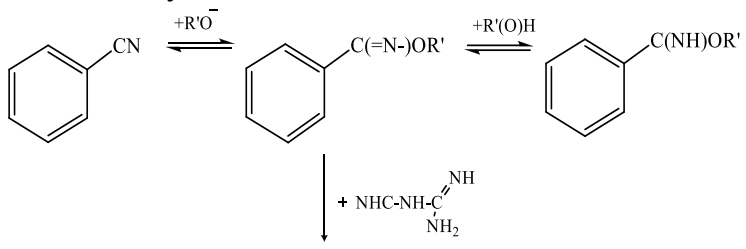<smiles>Cc1nc(N)nc(-c2ccccc2)n1</smiles>

$\mathrm{R}^{\prime}=\mathrm{H}_{3} \mathrm{COCH}_{2} \mathrm{CH}_{2}$

В противоположность авторам [10], нами впервые было установлено, что реакция между бензонитрилом (1) и дициандиамидом может протекать в диметилформамиде 
в присутствии эквимолярного количества $\mathrm{KOH}$, без участия в этом процессе алкоксид-иона по схеме 2, при этом значительно упрощается стадия выделения 6-(арилзамещенного)- 2,4-диамино-симм-триазина (2).

$$
\text { (3-8) }
$$

где $\mathrm{X}$ отсутствует $(3,9) ; \mathrm{X}=-\left(\mathrm{CH}_{2}\right)_{2}-(4,10)$; $\mathrm{X}=-(\mathrm{C}=\mathrm{O}) \mathrm{OC}(\mathrm{Me})_{2}-(5,11) ; \quad \mathrm{X}=-\mathrm{CH}_{2}-(6,12)$; $(7,13) ;(8,14)$.<smiles>[X]=C=Cc1cccc(Oc2ccccc2)c1</smiles>

Под действием полярного растворителя, в присутствии гидроокиси калия, нитрильная группа 3-френоксибензонитрила поляризуется. Далее в результате межмолекулярного взаимодействия с молекулой дициандиамида происходит образование промежуточного комплекса а. Затем быстро протекает нуклеофильная атака положительно заряженного атома углерода аминогруппой в положение 2 и миграция протона водорода к иминогруппе, в результате чего образуется вторая аминогруппа в положении 4 и образуется 2,4-диаминопроизводное 1,3,5-триазина.

В соответствие с предложенным механизмом образования 6-(3-феноксифенил-замещенных)-2,4-диамино-1,3,5-триазинов (9-14) лимитирующей стадией, вероятно, является образование промежуточного комплекса (а), что связано с атакой атома азота в 3-френоксифенилсодержащих нитрилах на атом углерода в дициандиамиде.

Данный способ является универсальным для получения 6-(арилзамещенных)-2,4диамино-симм-триазинов. Так, по схеме 2 132
В связи с этим нами предложен несколько иной механизм образования 6-(3-френоксифенил)-2,4-диамино-симм-триазинов (9-14) из 3-феноксифенилсодержащих нитрилов и дициандиамида в диметилформамиде представленный схемой 2: нами взаимодействием 3-феноксифенилсодержащих нитрилов (3-8) с дициандиамидом в диметилформамиде получены 6-(арилзамещенные)-2,4-диамино-симм-триазины (914).

Процесс проводят в реакторе емкостного типа с перемешивающим устройством при температуре $150-152{ }^{\circ} \mathrm{C}$ и мольном соотношении реагентов нитрил: дициандиамид: $\mathrm{KOH}=$ 1:1,2:1,2 в течении пяти-десяти часов. В качестве растворителя используют диметилформамид. После окончания реакции реакционную смесь разбавляют холодной водой и осаждают 6-(замещенные)-2,4-диамино-симмтриазины. Полученный продукт растворяют в хлороформе и очищают перекристаллизацией. Технологический выход продукта - 95 \%.

Исходя из предложенного, механизма нами установлено, что конверсия нитрилов и соответствующий этой конверсии выход триазинов (9-14) зависит от электронных и стерических факторов заместителей в исходных нитрилах (см. таблицу 1).

Как следует из таблицы 1, при прочих равных условиях (температура реакции 150-152 ${ }^{\circ} \mathrm{C}$, время реакции 10 часов) выход 3-феноксифенилсодержащих нитрилов изменяется от 50 до 95 \%. Причем наименьший выход 57 и 50 \% соответствует продуктам (11) и (12), в которых заместители у исходных нитрилов обладают наибольшим стерическим эффектом.

ПОЛЗУНОВСКИЙ ВЕСТНИК № 42018 
РАЗРАБОТКА УНИВЕРСАЛЬНОГО СПОСОБА ПОЛУЧЕНИЯ 6-(АРИЛЗАМЕЩЕННЫХ)-2,4-ДИАМИНО-СИММ-ТРИАЗИНОВ

Таблица 1 - Зависимость выходов 3-френоксифенилсодержащих 1,3,5-триазинов от пространственного строения исходных нитрилов

\begin{tabular}{|c|c|c|c|}
\hline № & Исходный нитрил & $\begin{array}{c}\text { Время реакции, } \\
\text { час } \\
\end{array}$ & $\begin{array}{c}\text { Выход триазина, } \\
\%\end{array}$ \\
\hline 2 & & 5 & 95 \\
\hline 9 & & 10 & 90 \\
\hline 10 & & 10 & 85 \\
\hline 11 & & 10 & 92 \\
\hline 12 & & 10 & 70 \\
\hline 13 & & 10 & 57 \\
\hline 14 & & 10 & 50 \\
\hline
\end{tabular}

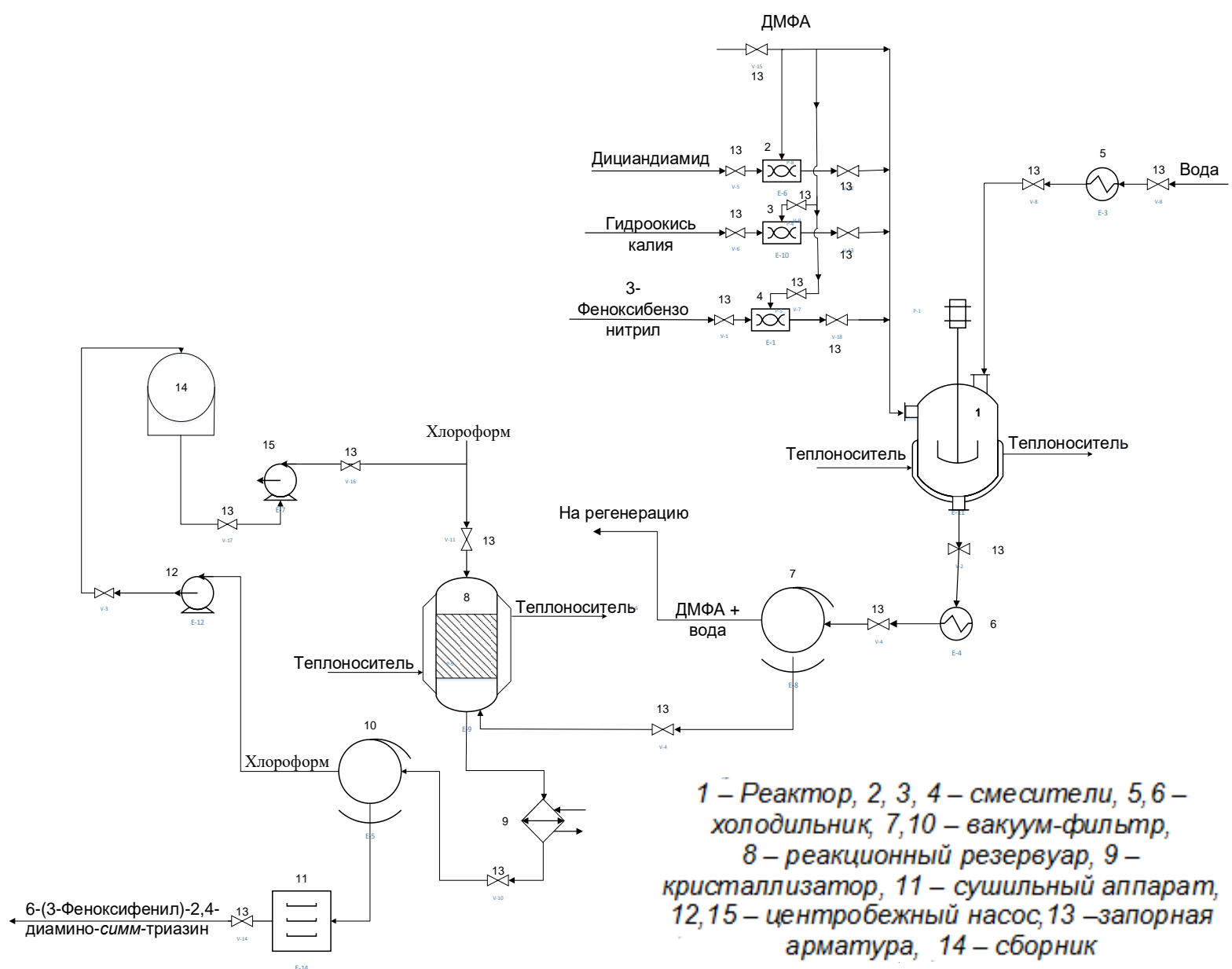


Рисунок 1 - Технологическая схема получения 6-(3-Феноксифенил)-2,4-диамино-симм-триазина

Для данного способа была разработана технологическая схема получения 2,4-диамино-симм-триазинов на примере синтеза 6(3-феноксифенил)-2,4-диамино-симм-триазина, которая показана на рисунке 1 . В смесители позиции 2 и 3 подают гидроокись калия и дициандиамид в мольном соотношении $1: 1$, а затем направляют в реактор позиции 1. Растворитель - ДМФА. Затем туда же подается 3феноксибензонитрил. Процесс ведется при температуре $150-152{ }^{\circ} \mathrm{C}$ в течение 10 часов. После реакционную массу обрабатывают холодной водой, в результате чего выпадают белые хлопья, которые отфильтровывают на вакуум-фильтре позиции 7. Растворитель ДМФА поступает на регенерацию. Полученный продукт перекристаллизовывают из хлороформа в реакционном резервуаре позиции 8. Выделившиеся кристаллы целевого продукта сушат в сушилке 11. Технологический выход продукта $90 \%$.

\section{ВЫводы}

Разработан универсальный способ получения замещенных 2,4-диамино-симм-триазинов и подобраны оптимальные параметры процесса, что позволяет достигать выхода от 50 до $95 \%$.

\section{СПИСОК ЛИТЕРАТУРЫ}

1. Химическая энциклопедия. М. : Сов. энцикл., 1988. - Т. 1. - С. 1209.

2. Энциклопедия полимеров. М. : Сов. энцикл., 1972. - Т. 1. - С. 654.

3. Кодолов, В И. Замедлители горения полимерных материалов / В. И. Кодолов. - М. : Химия, 1980.

4. Ogino, A., Matsumura, S., Fujita, T. J. Med. Chem. 1980. - № 23. - P. 23.

5. Пат. 3966728 США, МПК C07 D251/48, C07 D251/18, A61 K31/53. Benzoguanamine derivatives. / Nippon Shinyaku Co., Ltd. ; 29.06.1976.

6. Пат. 4333933 США, МПК C07 D401/12, A61P25/04, C07 D251/16, C07 D251/18.Benzoguanamine derivatives, their production and pharmaceutical compositions containing the same. / Shingo Matsumura, Hiroshi Enomoto, Yoshiaki Aoyagi, Yoshihisa Shibata. ; 8.06.1982.

7. Lipschitz, W., Stokey, E., J. Pharmacol. 1948. № 92. Р. 131.

8. Институт органического синтеза им. И.Я. Постовского УрО РАН / В. Н. Чарушин, О. Н. Чупахин ; Номер контракта: 02.435.11.3017
9. Пат. 2451678 РФ, МПК С 07 D 251/18. Способ получения 6-(3-фенокси-фенилзамещенных) 2,4-диамино-симм-триазинов / Ю. В. Попов, Т. К. Корчагина,В. С. Лобасенко ; ВолгГТУ. - 27.05.2012. 10.Гогин, Л. Л. Способы получения и перспективы создания современного малоотходного производства гуанаминов в России / Л. Л. Гогин, Е. Г. Жижина, З. П. Пай,В. Н. Пармон // Химия в интересах устойчивого развития. - 2009. - № 4 . C. $339-348$.

Попов Юрий Васильевич, доктор химических наук, профрессор, заведующий кафедрой «Технология основного органического и нефртехимического синтеза», Федеральное государственное бюджетное образовательное учреждение высшего образования Волгоградский государственный технический университет (ФГБОУ ВО ВолаГТУ), Россия, г. Волгоград, пр. Ленина, 28, e-mail: tons@vstu.ru.

Корчагина Татьяна Константиновна, кандидат химических наук, доцент, Федеральное государственное бюджетное образовательное учреждение высшего образования Волгоградский государственный технический университет (ФГБОУ ВО ВолаГТУ), Россия, 2. Волгоград, пр. Ленина, 28, еmail:tatkorchagina@mail.ru.

Лобасенко Виктория Сафиулловна, кандидат химических наук, доцент, Федеральное государственное бюджетное образовательное учреждение высшего образования Волгоградский государственный технический университет (ФГБОУ ВО ВолаГТУ), Россия, е. Волгоград, пр. Ленина, 28, e-mail:viktori_2008@bk.ru.

Букова Инна Владимировна, магистрант ВолГТУ, Федеральное государственное бюджетное образовательное учреждение высшего образования Волгоградский государственный технический университет (ФГБОУ ВО ВолгГТУ), Россия, г. Волгоград, пр. Ленина, 28, e-mail: inna.bukova@yandex.ru.

Немцева Наталья Валерьевна магистрант ВолГТУ, Федеральное государственное бюджетное образовательное учреждение высшего образования Волгоградский государственный технический университет (ФГБОУ ВО ВолгГТУ), Россия, г. Волгоград, пр. Ленина, 28, e-mail: natusik.bask@mail.ru. 